\title{
Phytoprotection
}

\section{Molecular tracking new migrations of an old pathogen : the re-emergence of potato late blight}

\section{S.B. Goodwin}

Volume 80, numéro 2, 1999

URI : https://id.erudit.org/iderudit/706183ar

DOI : https://doi.org/10.7202/706183ar

Aller au sommaire du numéro

Éditeur(s)

Société de protection des plantes du Québec (SPPQ)l

ISSN

0031-9511 (imprimé)

1710-1603 (numérique)

Découvrir la revue

Citer cet article

Goodwin, S. (1999). Molecular tracking new migrations of an old pathogen : the re-emergence of potato late blight. Phytoprotection, 80(2), 85-95.

https://doi.org/10.7202/706183ar d'utilisation que vous pouvez consulter en ligne.

https://apropos.erudit.org/fr/usagers/politique-dutilisation/ 


\title{
Molecular tracking new migrations of an old pathogen : the re-emergence of potato late blight
}

\author{
Stephen B. Goodwin \\ USDA-ARS, Department of Botany and Plant Pathology, 1155 Lilly Hall, \\ Purdue University, West Lafayette, IN 47907-1155, USA
}

PHYTOPROTECTION $80: 85-95$

Late blight of potato is caused by the oomycete Phytophthora infestans (Mont.) de Bary. Although often considered to be fungi, oomycetes are phylogenetically much more closely related to certain groups of algae and are now considered part of a separate kingdom, the Stramenopila. Thus, in an evolutionary context $P$. infestans is more like an alga that has lost its chlorophyll rather than a fungus. However, $P$. infestans is very similar to a fungus morphologically and in the ecological niche it fills.

This organism is diploid at all stages in its life cycle and requires two mating types, designated $A 1$ and $A 2$, for sexual reproduction. The result of sexual reproduction is an oospore, which is resistant to environmental extremes (e.g., freezing, drying) and can survive for many years in soil. Asexual reproduction is by sporangia, which are produced in huge quantities on the surface of infected tissue. The sporangia are easily detached and highly adapted for aerial dispersal. However, they do not survive freezing or drying so are not persistent in the environment. Sporangia can germinate and penetrate plant parts directly, but if exposed to water and chilled they germinate indirectly by releasing zoospores. As implied by their name, zoospores are motile and can swim towards a suitable host with the aid of two flagella. Each sporangium can release many zoospores.

Late blight is one of the most destructive plant diseases known and can decimate entire fields of potatoes or tomatoes in only a few weeks. In addition to destroying the stems and foliage, the pathogen attacks tubers and fruits and can cause $100 \%$ yield loss. After being controlled for decades in most of the developed countries, late blight re-appeared during the 1980 s and 1990s. The purpose of this paper is to summarize what is known about the reemergence of late blight and to suggest ways to minimize similar problems with this and other diseases in the future.

\section{MOLECULAR MARKERS FOR PATHOGEN TRACKING}

More is known about the biology and past history of $P$. infestans than almost any other plant pathogen. Much of this information was derived from the application of molecular marker technologies. Two types of molecular marker have provided the majority of information: the allozyme loci glucose-6-phosphate isomerase (Gpi) and peptidase $(P e p)$; and DNA fingerprinting with probe RG57.

Note du rédacteur : le texte ci-dessus est présenté tel que soumis / Editor's note : the above text is presented as submitted. 
Allozymes are genetic variants at the same enzyme locus. Each allozyme has a slightly different amino acid composition that alters its mobility in an electric field but does not affect its catalytic ability. These amino acid variants are detected as different bands on electrophoretic gels. The bands are visualized by soaking the gels in a solution containing the substrate for each particular enzyme. When the enzyme performs its catalytic function, it generally causes one of the chemicals in the staining solution to form a colored precipitate which accumulates in a band corresponding to the region of enzyme activity. So far, there are at least seven known alleles for Gpi in $P$. infestans and five for Pep.

DNA fingerprinting uses probe RG57 (Goodwin et al. 1992a). This is a moderately repetitive DNA fragment that was cloned from the nuclear genome of $P$. infestans. When total nuclear DNA of $P$. infestans is digested with the restriction enzyme Eco RI, size fractionated on an electrophoretic gel, blotted to a membrane and hybridized with RG57, each isolate generally shows from 5-15 bands which are highly variable among isolates. Scoring all of the bands together provides a specific DNA "fingerprint" for each isolate. Genetic analyses of the fingerprint patterns have shown that each band behaves as a separate Mendelian locus, and most of the loci are unlinked (Goodwin et al. 1992a). This provides a powerful tool for analyzing the population biology of $P$. infestans.

Other molecular markers also have been used for $P$. infestans. These include single-copy nuclear and mitochondrial DNA restriction fragment length polymorphisms (Carter et al. 1990; Goodwin 1991), random amplified polymorphic DNA (Goodwin et al. 1999), and amplified fragment length polymorphisms. Although these provide additional information, they have mostly just confirmed what was already known from analyses of allozymes and DNA fingerprints so will not be discussed further here.
In addition to the molecular markers, a number of phenotypic traits also are analyzed for $P$. infestans. These include mating type ( $A 1$ or $A 2$ ), virulence to a number of potato and tomato resistance genes, and resistance to the systemic fungicide metalaxyl.

\section{THE ORIGIN OF POTATO LATE BLIGHT}

Analyses with all of the above markers revealed that $P$. infestans probably evolved in a limited area in the highlands of central Mexico. This is the area in which both mating types were first found in approximately equal frequency (Niederhauser 1991). It also has the highest diversity for almost every molecular and phenotypic marker analyzed, including virulence (Goodwin et al. 1995b), allozymes (Goodwin et al. 1992b; Tooley et al. 1985) and DNA fingerprints (Goodwin 1996; Goodwin et al. 1992b). Molecular markers in this geographic area are in Hardy-Weinberg equilibrium (Goodwin et al. 1992b; Tooley et al. 1985), an indication of regular sexual recombination.

The original hosts for $P$. infestans were probably wild species of Solanum. Mexico is a secondary center of diversity for the genus Solanum (Correll 1962), with many endemic species. Some of these species, particularly $S$. demissum, contain numerous specific genes for resistance against $P$. infestans that probably developed during a long period of coevolution.

Cultivated potatoes evolved in the Andes region of South America and probably were not exposed to $P$. infestans until the 1800s. This probably explains the high susceptibility of cultivated potatoes to $P$. infestans (there was no selection for resistance) and also may indicate why it took more than 250 years after the introduction of potatoes to Europe before late blight appeared (Goodwin 1996). In a sense, late blight of potato and tomato as we know it today is a man-made disease created by the movement of host and pathogen to new locations. 


\section{POTATO LATE BLIGHT : 1843-1976}

The first epidemic of late blight outside Mexico probably occurred in the eastern United States during 1843 (Stevens 1933). An analysis of reports of the new potato disease indicated a probable focal point near New York or New Jersey. From its point of introduction, the pathogen spread rapidly and by the end of 1845 late blight was known throughout the northeastern United States, from North Carolina in the south, west to Illinois, and north into the Maritime provinces of Canada and the southern portions of Ontario and Québec (Stevens 1933). Most of this rapid spread probably was from field to field as airborne sporangia, although some movement of infected potato tubers also may have occurred.

A similar pattern occurred in Europe. The disease was first reported in Belgium during late June 1845 , and by the end of the year it had spread east into Germany and northern Poland, south through France and possibly northern Italy, north into Scandinavia, and west across Britain and Ireland (Bourke 1964). Most of this spread probably was by airborne sporangia. The disease destroyed the potato crop in Ireland during 1845 and subsequent years leading to the great Irish potato famine, which reduced the human population of that island by more than half due to starvation and emigration.

Recent analyses with molecular markers have shown that these initial migrations probably occurred in three steps (Goodwin 1997; Goodwin et al. 1994b). The first step probably was from Mexico to the USA during or shortly before 1843. Transport most likely was in tubers of wild Solanum species (Goodwin 1997). This migration may have included a number of genotypes, although it probably did not include the A2 mating type (Goodwin et al. 1994a). The second step probably was from the USA to Europe in cultivated potato tubers during 1844 or 1845 and may have included only a single genotype, US-1 (Goodwin et al. 1994b). The third step probably was from Europe to the rest of the world in seed or ware potatoes beginning after 1845 (summarized in Goodwin 1997).

The result of these early migrations is that a single clonal lineage, designated US-1, was spread throughout the world. All the members of this lineage may be descended from a single individual that was transported from Mexico to the United States during 1843.

The widespread distribution of US-1 is important for understanding the biology and epidemiology of late blight. If the above scenario is correct, then for more than 130 years late blight in most of the world was caused exclusively by US- 1 and its clonal descendants. AImost all of the genetic variation within the species remained behind in Mexico. The US-1 clonal lineage is A1 mating type and, by itself, is limited to asexual reproduction. Clonal populations of US1 must survive winter cold and summer drought as mycelium inside living tissue, mostly potato tubers but also possibly in tomato fruits (Vartanian and Endo 1985). Because epidemics were caused by the same clone from year to year, growers knew what to expect and plant pathologists could devise effective strategies for disease management. During this time, epidemics were rare and sporadic and mostly controlled with a combination of crop hygiene (planting disease-free seed, removing cull piles) and judicial use of fungicides.

\section{THE RESURGENCE OF LATE BLIGHT IN EUROPE : 1976-1990}

This changed during the early 1980s in Europe, when late blight suddenly became much more difficult to control. It was soon realized that this was due at least in part to the development of resistance to the most effective fungicide, metalaxyl. This fungicide provided almost complete protection against epidemics caused by US-1. However, resistance developed rapidly during the 1980s. This stimulated an increase in research, and it was soon discovered 
that, in addition to fungicide resistance, the A2 mating type also was present. Analyses of stored cultures showed that the A2 mating type had been present in western Europe at least since 1981 (Hohl and Iselin 1984).

When these populations were analyzed with molecular markers, it was soon discovered that the increased disease problems were due to the migration of new genotypes of $P$. infestans from Mexico (Fry et al. 1993; Goodwin et al. 1994b; Spielman et al. 1991). These new populations were different for mating type, allozymes, DNA fingerprints and mitochondrial DNA markers (Fry et al. 1993), and also had a higher diversity for virulence (Drenth et al. 1994; Sujkowski et al. 1996).

In addition, they must have had a much higher fitness, because they rapidly replaced US-1 in all locations analyzed. Total replacement of US- 1 usually occurred within 2-4 years of the first detection of new genotypes (Fry et al. 1993). Similar replacements of US1 by new genotypes also began to occur in Africa, Asia and South America in addition to Europe.

\section{THE RESURGENCE OF POTATO (AND TOMATO) LATE BLIGHT IN THE UNITED STATES AND CANADA : 1990-1998}

Those of us in northern North America sat by smugly as the new populations swept through Europe. We were confident that the same things would not happen on our side of the Atlantic. Some speculated that the rapid development of fungicide resistance in Europe must have been due to inappropriate applications, not in accordance with the label instructions. Others thought the problems must be the result of careless crop sanitation, or to the importation of potatoes from North Africa or Asia. Such problems would never occur in North America; we were much too careful for that. We also had an unseen ally. In most years in the potato-growing regions of North America, the weather is a little warmer and drier than in Europe and, therefore, not as favorable for $P$. infestans.

This all changed beginning in 1992. Late blight epidemics suddenly appeared in many of the potato-growing regions of the USA and Canada (Fry and Goodwin 1997b; Goodwin et al. 1995a). In contrast to previous years, these epidemics caused much more damage and were not easily controlled with metalaxyl. Similar problems occurred on tomatoes. Molecular marker analyses soon revealed the cause of the epidemics: new genotypes that were A2 mating type and highly resistant to metalaxyl (Goodwin et al. 1995a). Surprisingly, these genotypes were not related to the new genotypes in Europe. Instead, they were identical to genotypes identified a few years earlier in northwestern Mexico (Goodwin et al. 1995a).

The same pattern continued during 1993 as the new genotypes spread to additional areas. By 1996 it was clear that late blight in the United States and Canada was caused primarily by a handful of genotypes (Table 1). It was also clear that US-1 was disappearing rapidly (Fig. 1). The replacement of US-1

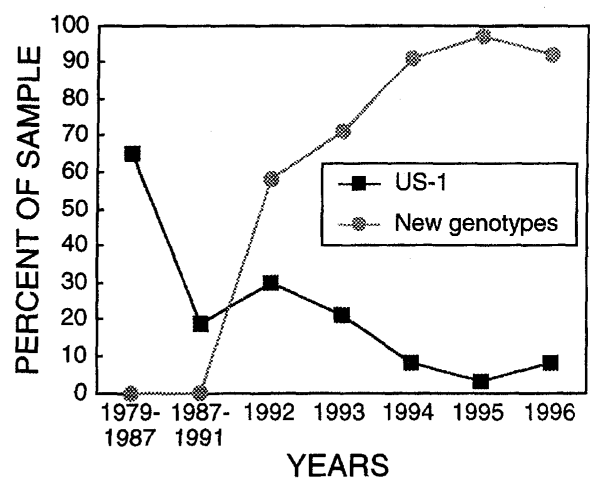

Figure 1. Replacement of the US-1 clonal lineage of Phytophthora infestans in the United States and Canada by new genotypes that were first detected during 1992 (genotypes US-7 and above). This analysis is based on data from 1112 isolates. The US-6 clonal lineage probably migrated into the United States and Canada during the late 1970 s or early 1980 s so was excluded from this analysis. 
Table 1. The major genotypes of Phytophthora infestans detected in the United States and Canada from 1979 through 1996

\begin{tabular}{|c|c|c|c|c|c|c|c|}
\hline Genotype & $\begin{array}{l}\text { Mating } \\
\text { type }\end{array}$ & $\frac{\text { Allozyme }}{\text { Gpi }^{a}}$ & $\frac{\text { genotype }}{\text { Pep }^{\mathrm{b}}}$ & RG57 DNA fingerprint ${ }^{c}$ & $\begin{array}{l}\text { Metalaxyl } \\
\text { sensitivity }^{d}\end{array}$ & $\begin{array}{l}\text { Primary } \\
\text { host(s) }\end{array}$ & Comments \\
\hline US-1 & A1 & $86 / 100$ & $92 / 100$ & 1011101011001101000110011 & $\mathrm{~S}$ & $\begin{array}{l}\text { potato, } \\
\text { tomato }\end{array}$ & $\begin{array}{l}\text { Old clonal lineage found } \\
\text { throughout the world }\end{array}$ \\
\hline US-6 & A1 & $100 / 100$ & $92 / 100$ & 1011111001001100010110011 & $\mathrm{R}$ or $\mathrm{S}$ & $\begin{array}{l}\text { tomato, } \\
\text { potato }\end{array}$ & $\begin{array}{l}\text { Introduced from northwestern } \\
\text { Mexico during the late 1970s or } \\
\text { early 1980s. Replaced by US-7 }\end{array}$ \\
\hline US-7 & A2 & $100 / 111$ & $100 / 100$ & 1001100001001101010110011 & $\mathrm{R}$ & tomato & $\begin{array}{l}\text { Introduced from northwestern } \\
\text { Mexico during the early 1990s. } \\
\text { Replaced US-1 and US-6 on } \\
\text { tomato }\end{array}$ \\
\hline US-8 & A2 & $100 / 111 / 122$ & $100 / 100$ & 1001100001001101000110111 & $\mathrm{R}$ & potato & $\begin{array}{l}\text { Introduced from northwestern } \\
\text { Mexico during the early 1990s. } \\
\text { Replaced US- } 1 \text { and US-6 on } \\
\text { potato }\end{array}$ \\
\hline US-11 & A1 & $100 / 100 / 111$ & $100 / 100$ & 1010111001001101010110011 & $\mathrm{R}$ & potato & $\begin{array}{l}\text { Possibly generated by } \\
\text { recombination in the Pacific } \\
\text { northwest. May be a competitor } \\
\text { for US-8 }\end{array}$ \\
\hline US-17 & A1 & $100 / 122$ & $100 / 100$ & 1010001000001101010110011 & $\mathrm{R}$ & tomato & $\begin{array}{l}\text { Probably a new sexual } \\
\text { recombinant. Replacing US-7 }\end{array}$ \\
\hline
\end{tabular}

a Glucose-6-phosphate isomerase.

b Peptidase.

c Presence (1) or absence (0) of RG57 fingerprint bands 1 - 25 (Goodwin et al. 1992a) are indicated from left to right. DNA fingerprint band 4 is not reproducible and should not be used for genotype identification.

${ }^{d} \mathrm{R}=$ resistant; $\mathrm{S}=$ sensitive. 
began during the late 1970 s or early 1980 s with the introduction of the US6 genotype from northwestern Mexico (Goodwin et al. 1994a). It accelerated rapidly during the 1990s when the US7 and US-8 genotypes began replacing both US-1 and US-6. By 1996 the replacement of US-1 by new genotypes was almost complete (Fig. 1). US-1 is still found occasionally, but it makes up a very small proportion of the total $P$. infestans population (Goodwin et al. 1998).

In addition to replacement, there was some evidence for possible sexual reproduction. The previously dominant genotypes (US-1, US-6) were A1 mating type, but the new migrants were mostly A2. Thus, for the first time in the USA and Canada there was the possibility of sexual recombination. The first evidence for probable recombinant genotypes in the field was in British Columbia during 1992 (Goodwin et al. 1995a). Other evidence for possible recombinant genotypes has been found in the Columbia Basin of Washington and Oregon (Miller et al. 1997) and in New York (Goodwin et al. 1998). Sexual reproduction could make late blight much more difficult to control by providing a long-lived source of inoculum in soil and by generating a succession of new genotypes with potentially higher fitness.

The consequences of these migrations were devastating to many potato and tomato growers. The northeastern
United States was particularly hard hit, and many potato growers lost their family farms (Fry and Goodwin 1997a; Table 2). The problem was not only lost production, but also the destruction of crops after harvest (Fry and Goodwin 1997b). Late blight in stored potatoes facilitates entry of many other organisms, including the bacteria that cause soft rot. Stored potatoes from infected fields often "melted" during storage, creating a horrible, smelly mess.

\section{MECHANISMS OF MIGRATION}

How could such problems develop? Clearly, the difficulties were caused by the migration of new genotypes. However, the means of long-distance transport were not known. Molecular markers provided some of the answers.

Once within the United States and Canada, long-distance transport occurred in infected potato tubers. Proof of this came from Florida. Late blight in two fields in southern Florida during 1993 was caused by US-1 (Goodwin et al. 1995a). This was the only region in Florida in which US-1 was detected that year, and the area had essentially no late blight for several years prior to 1993. The seed tubers for those fields came from Maine and North Dakota, and US1 was known to be present in those states during 1992, the year the seed was produced (Goodwin et al. 1995a).

Table 2. Economic impact of late blight on one farm in the northeastern United States during 1994 (data courtesy of W. E. Fry, Cornell University)

Potato acreage

Cost of production

Cost of pesticide spray, 1994

Average (historical) yield 
The next year, fields on one of the same farms were infected with US-8. That year, the seed was purchased from Maine, and US-8 was confirmed in samples from the same seed lot. US-1 was not found in Florida that year (Goodwin et al. 1998). The only likely source of inoculum for US-1 in southern Florida during 1993 and for US-8 during 1994 was infected seed potato tubers.

Movement of infected potato seed explains most of the long-distance migration of $P$. infestans within the United States and Canada, but does not explain how the new strains arrived in northern North America originally. Importation of potato tubers, especially from Mexico, is prohibited, so it seems highly unlikely that infected tubers could have been imported from Mexico into the United States or Canada. The production areas of northwestern Mexico are surrounded by arid mountains and deserts which preclude airborne movement of sporangia over long distances. Escape from culture collections in the USA or Canada seems remote, because the initial occurrences of new strains were distant from research centers and those cultures are maintained under strict quarantine.

This leaves the most likely culprit as infected tomato fruits. Tomatoes are imported from Mexico into the United States for fresh consumption. They probably are not screened as carefully for late blight, because it is usually considered only a potato disease. The area of northwestern Mexico that the DNA fingerprint data indicated as the probable source of the US-7 and US-8 genotypes also produces tomatoes.

Proof of the tomato-fruit connection finally came during 1995 when infected tomatoes from northwestern Mexico were intercepted in South Carolina (Goodwin 1997). Infection by $P$. infestans was confirmed, although no isolations were made, so it was not possible to confirm the genotype. However, the US-1, US-7 and US-8 genotypes have been recovered from infected tomato fruits. Therefore, movement of $P$. infestans in infected tomato fruits probably is a highly effective mechanism for long-distance dispersal.
Another potential method for longdistance transport of $P$. infestans is in tomato transplants. Most of the evidence for this is anecdotal. There have been rumors of movement of infected tomato transplants from Florida into New York, and from California into Washington and even British Columbia (Fry and Goodwin 1997a, 1997b). The pathogen has been isolated from tomatoes in greenhouses. However, as far as I am aware, $P$. infestans has never been confirmed on tomato transplants. The hypothesis of movement in tomato transplants needs to be tested by thorough checking in the future.

Over short distances, $P$. infestans can disperse by airborne sporangia. Nearby fields are no longer safe once $P$. infestans has been detected within a region. This was shown dramatically on home garden tomatoes in New York during 1993. From an initial focus in one county (possibly started by infected transplants), the disease spread out over six counties in less than 4 weeks (Fry and Goodwin 1997b). This spread probably was by aerial dispersal of sporangia and indicates how rapid asexual reproduction can facilitate migration by increasing the number of infective propagules available for transport.

\section{MECHANISMS OF HIGHER FITNESS IN NEW POPULATIONS}

There are many potential mechanisms to explain the higher fitness of the migrating genotypes. The most obvious one is resistance to the fungicide metalaxyl. The new genotypes US-7 and US-8 are highly resistant to metalaxyl, whereas all isolates of US-1 from the United States and Canada tested to date have been sensitive (Goodwin et al. 1996). Metalaxyl was still widely used at the time of the 1990s migrations and would have applied tremendous selection pressure in favor of the migrant genotypes.

The new genotypes also generally had higher virulence compared to the old US-1 clonal lineage (Goodwin et al. 1995b; Fig. 2). Virulence probably was 

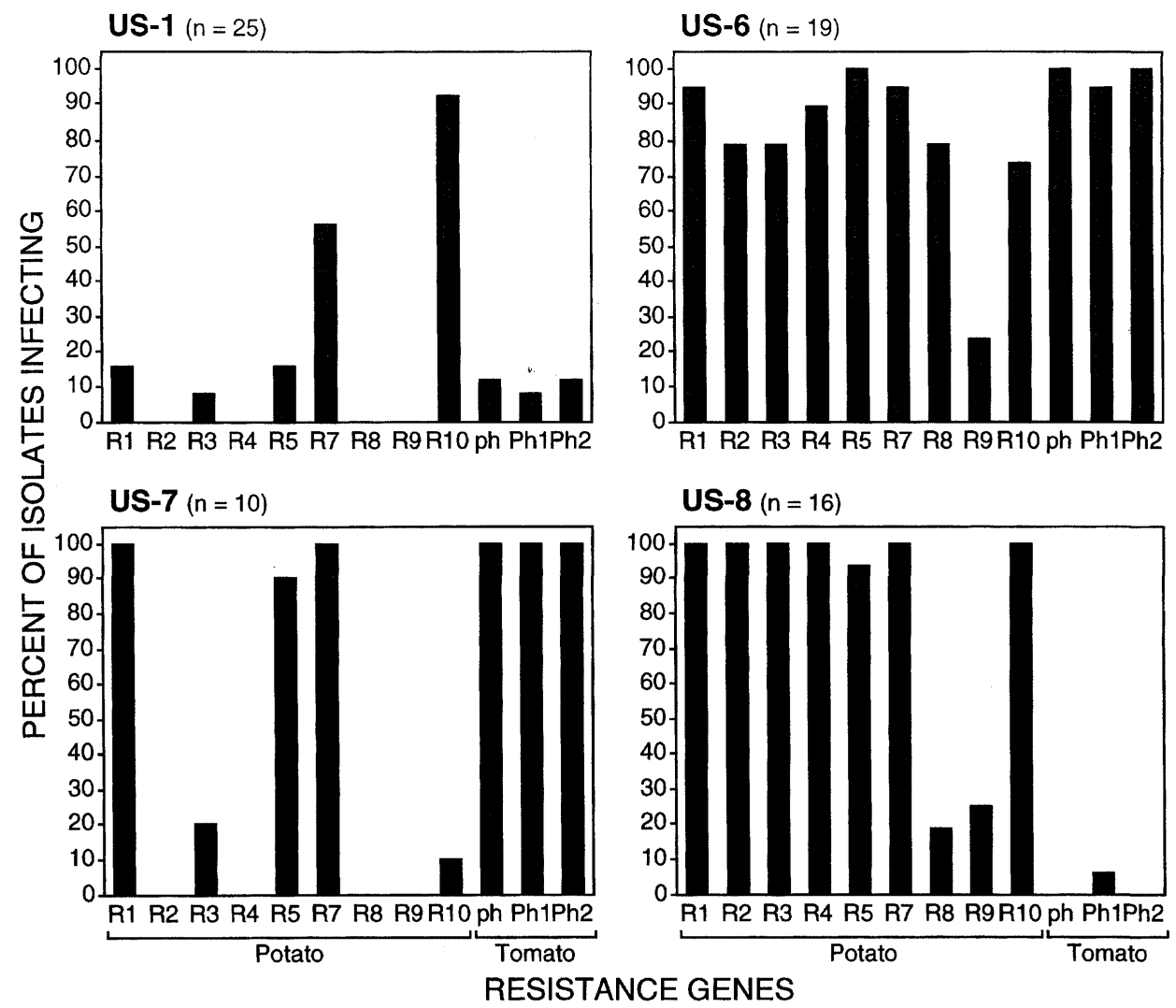

Figure 2. Virulence of isolates of Phytophthora infestans from the United States and Canada to potato and tomato resistance genes analyzed according to clonal lineage.

not a major factor in the higher fitness of new genotypes, because most potato and tomato cultivars in the United States and Canada do not have resistance genes. However, higher virulence may have helped with infection of the rare cultivars that did have one or more resistance genes, and may indicate that the new genotypes were from populations that were exposed to resistance genes (e.g., from wild hosts) in the recent past.

Evidence is beginning to accumulate that the new genotypes are more aggressive. They may cause greater infection of potato tubers (Lambert and Currier 1997), have shorter latent periods, and cause larger lesions with more sporulation (Kato et al. 1997; Miller et al. 1998). Greater aggressiveness would have allowed the new genotypes to replace US-1 in the absence of other contributing factors.

Another possible mechanism of greater fitness, at least in Europe, is sexual reproduction. There is now good evidence for sexual reproduction of the new genotypes in Poland (Sujkowski et al. 1994) and the Netherlands (Drenth et al. 1994, 1995). The sexual cycle generates an additional source of inoculum as oospores that could provide a huge advantage compared to asexual reproduction alone. Large numbers of overwintering oospores could overwhelm the low level of survival of asexual lineages in living tissue.

A final potential explanation for the mechanism of greater fitness could be Muller's ratchet. This phenomenon occurs when the most fit genotype 
within a clonal lineage fails to survive by chance (genetic drift). When this occurs, the mean fitness of the clonal population decreases (Muller 1964). During many asexual generations, the fitness can ratchet downwards considerably. The speed of the ratchet depends on the rate of mutation and the population size; it proceeds fastest with high mutation rates and small populations. Populations can reach "mutational meltdown" after only $10^{3}$ asexual generations (Lynch et al. 1993). The US-1 clonal lineage may have experienced near this number of asexual generations by the 1980s and 1990s (Drenth et al. 1993; Goodwin 1997), so its fitness could have been much lower than when it originally escaped from Mexico. This may explain the relatively low fitness of US-1 compared to US-7 and US-8, which probably arose from recent sexual populations. Muller's ratchet could lower all aspects of fitness so most studies that evaluate differences in fitness components between US- 1 and the new genotypes may find that US- 1 is less fit.

\section{CONCLUSIONS}

The global resurgence of late blight was caused by the migration of new genotypes with higher fitness. These new genotypes originated in Mexico, the center of diversity for the pathogen. This underscores the importance of preventing new migrations of old pathogens, particularly from their original centers of diversity which may contain huge reservoirs of genetic variation.

There appear to have been at least three recent migrations out of Mexico that brought different genotypes to Europe, east Asia and northern North America. The new European populations already may have spread to Africa and South America. There is still a great potential for genetic exchange among these regions. The US-7 and US-8 genotypes may be even more damaging in Europe than in North America. Conversely, the European genotypes may cause more problems in North America. Those are questions we do not want answered. Hopefully, quarantine procedures can minimize future intercontinental migrations.

The long-term consequences of these migrations for potato and tomato producers in North America are not known. Two potential outcomes seem likely. One is the development of sexually reproducing populations, which may be occurring in certain parts of Europe. The other is that there will be a gradual replacement of clonal lineages over years, as new clones with higher fitness are generated by occasional sexual recombination or possibly by rare mutations within lineages.

Clonal replacement seems to be occurring in northwestern Mexico (S.B. Goodwin, unpublished), the original source for many of these genotypes, and already seems to be occurring on tomatoes in the United States and Canada. Tomatoes originally were infected by US- 1 , which gave way to US- 6 during the late 1980s and early 1990s (Goodwin et al. 1994a). US-7 replaced US-6 from about 1992-1995 (Goodwin et al. 1995a, 1998). Since 1996 an even newer genotype, US-17, has been replacing US-1 (Goodwin et al. 1998). A similar situation may be occurring on potatoes with the appearance of US-11.

This means that it is not possible to predict which genotypes will occur in a location from year to year. Genotypes in seed tubers provided a much better prediction of what would occur in a field than the genotypes that were present in the same location the year before (Goodwin et al. 1998). Planting disease-free seed and minimizing other potential sources of inoculum are of paramount importance with a clonal pathogen population.

Molecular markers provide a powerful tool for tracking pathogen migrations, but are not a substitute for traditional monitoring and quarantine activities. Better communication among growers, scientists and quarantine officials is essential to minimize future migrations and reduce the damage they cause. We must always remain vigilant for new forms of old foes that may be 
waiting for transport to pristine agricultural areas.

\section{ACKNOWLEDGMENTS}

I thank Bill Fry for many years of postdoctoral support during which most of the work for this paper was performed. I also thank the USDA-Agricultural Research Service and the Department of Botany and Plant Pathology, Purdue University for current support, and Larry Dunkle for helpful comments on a previous draft of the manuscript.

\section{REFERENCES}

Bourke, P.M.A. 1964. Emergence of potato blight, 1843-46. Nature 203 : 805-808.

Carter, D.A., S.A. Archer, K.W. Buck, D.S. Shaw, and R.C Shattock. 1990. Restriction fragment length polymorphisms of mitochondrial DNA of Phytophthora infestans. Mycol. Res. 94 : 1123-1128.

Correll, D.S. 1962. The potato and Its wild relatives. Texas Research Foundation, Renner, TX.

Drenth, A., L.J. Turkensteen, and F. Govers. 1993. The occurrence of the A2 mating type of Phytophthora infestans in the Netherlands; significance and consequences. Neth. J. Plant Pathol. 99 supplement $3: 57-67$.

Drenth, A., I.C.Q. Tas, and F. Govers. 1994. DNA fingerprinting uncovers a new sexually reproducing population of Phytophthora infestans in the Netherlands. Eur. J. Plant Pathol. 100 : 97-107.

Drenth, A., E.M. Janssen, and F. Govers. 1995. Formation and survival of oospores of Phytophthora infestans under natural conditions. Plant Pathol. 44 : 86-94.

Fry, W.E., and S.B. Goodwin. 1997a. Resurgence of the Irish potato famine fungus. BioScience 47 : 363-371.

Fry, W.E., and S.B. Goodwin. 1997b. Re-emergence of potato and tomato late blight in the United States. Plant Dis. 81 : 13491357.

Fry, W.E., S.B. Goodwin, A.T. Dyer, J.M. Matuszak, A. Drenth, P.W. Tooley, L.S. Sujkowski, Y.J. Koh, B.A. Cohen, L.J. Spielman, K.L. Deahl, D.A. Inglis, and K.P. Sandlan. 1993. Historical and recent migrations of Phytophthora infestans : chronology, pathways and implications. Plant Dis. 77 : 653-661.
Goodwin, S.B. 1991. DNA polymorphisms in Phytophthora infestans : the Cornell experience. Pages 256-271 in J.A. Lucas, R.C. Shattock, D.S. Shaw, and L.R. Cooke, (eds.), Phytophthora. Cambridge University Press, Cambridge, UK.

Goodwin, S.B. 1996. Origin and ecology of Phytophthora infestans. Rev. Mex. Fitopatol. $14: 143-147$.

Goodwin, S.B. 1997. The population genetics of Phytophthora. Phytopathology 87 : 462-473.

Goodwin, S.B., A. Drenth, and W.E. Fry. 1992a. Cloning and genetic analyses of two highly polymorphic, moderately repetitive nuclear DNAs from Phytophthora infestans. Curr. Genet. 22 : 107-115.

Goodwin, S.B., L.J. Spielman, J.M. Matuszak, S.N. Bergeron, and W.E. Fry. 1992b. Clonal diversity and genetic differentiation of Phytophthora infestans populations in northern and central Mexico. Phytopathology 82 : 955-961.

Goodwin, S.B., B.A. Cohen, K.L. Deahl, and W.E. Fry. 1994a. Migration from northern Mexico as the probable cause of recent genetic changes in populations of Phytophthora infestans in the United States and Canada. Phytopathology 84 : 553558.

Goodwin, S.B., B.A. Cohen, and W.E. Fry. 1994b. Panglobal distribution of a single clonal lineage of the Irish potato famine fungus. Proc. Natl. Acad. Sci. USA 91 : 11591-11595.

Goodwin, S.B., L.S. Sujkowski, A.T. Dyer, B.A. Fry, and W.E. Fry. 1995a. Direct detection of gene flow and probable sexual reproduction of Phytophthora infestans in northern North America. Phytopathology $85: 473-479$.

Goodwin, S.B., L.S. Sujkowski, and W.E. Fry. 1995b. Rapid evolution of pathogenicity within clonal lineages of the potato late blight disease fungus. Phytopathology 85 : 669-676.

Goodwin, S.B., L.S. Sujkowski, and W.E. Fry. 1996. Widespread distribution and probable origin of resistance to metalaxyl in clonal genotypes of Phytophthora infestans in the United States and western Canada. Phytopathology $86: 793-800$.

Goodwin, S.B., C.D. Smart, R.W. Sandrock, K.L. Deahl, Z.K. Punja, and W.E. Fry. 1998. Genetic change within populations of Phytophthora infestans in the United States and Canada during 1994 to 1996 : role of migration and recombination. Phytopathology 88 : 939-949. 
Goodwin, S.B., D.E. Legard, C.D. Smart, M. Levy, and W.E. Fry. 1999. Gene flow analysis of molecular markers confirms that Phytophthora mirabilis and $P$. infestans are separate species. Mycologia $91: 796-810$.

Hohl, H.R., and K. Iselin. 1984. Strains of Phytophthora infestans with A2 mating type behaviour. Trans. Br. Mycol. Soc. 83 : 529-530.

Kato, M., E.S. Mizubuti, Goodwin, S.B., and W.E. Fry. 1997. Sensitivity to protectant fungicides and pathogenic fitness of clonal lineages of Phytophthora infestans in the United States. Phytopathology 87 : 973-978.

Lambert, D.H., and A.I. Currier. 1997. Differences in tuber rot development for North American clones of Phytophthora infestans. Am. Potato J. 74 : 39-43.

Lynch, M., R. Bürger, D. Butcher, and W. Gabriel. 1993. The mutational meltdown in asexual populations. J. Hered. $84: 339$ 344.

Miller, J.S., P.B. Hamm, and D.A. Johnson. 1997. Characterization of the Phytophthora infestans population in the Columbia Basin of Oregon and Washington from 1992 to 1995 . Phytopathology 87 : 656660.

Miller, J.S., D.A. Johnson, and P.B. Hamm. 1998. Aggressiveness of isolates of Phy tophthora infestans from the Columbia Basin of Washington and Oregon. Phytopathology 88 : 190-197.

Muller, H.J. 1964. The relation of recombination to mutational advance. Mutat. Res. $1: 2-9$.
Niederhauser, J.S. 1991. Phytophthora infestans: The Mexican connection. Pages 25-45 in J.A. Lucas, R.C. Shattock, D.S. Shaw, and L.R. Cooke (eds.), Phytophthora. Cambridge University Press, Cambridge, UK.

Spielman, L.J., A. Drenth, L.C. Davidse, L.J. Sujkowski, W.K. Gu, P.W. Tooley, and W.E. Fry. 1991. A second world-wide migration and population displacement of Phytophthora infestans? Plant Pathol. $40: 422-430$.

Stevens, N.E. 1933. The dark ages in plant pathology in America: 1830-1870. J. Wash. Acad. Sci. 23 : 435-446.

Sujkowski, L.S., S.B. Goodwin, A.T. Dyer, and W.E. Fry. 1994. Increased genotypic diversity via migration and possible occurrence of sexual reproduction of Phy tophthora infestans in Poland. Phytopathology $84: 201-207$.

Sujkowski, L.S., S.B. Goodwin, and W.E. Fry. 1996. Changes in specific virulence in Polish populations of Phytophthora infestans : 1985-1991. Eur. J. Plant Pathol. $102: 555-561$.

Tooley, P.W., W.E. Fry, and M.J. Villarreal Gonzalez. 1985. Isozyme characterization of sexual and asexual Phytophthora infestans populations. J. Hered. 76 : 431435.

Vartanian, V.G., and R.M. Endo. 1985. Overwintering hosts, compatibility types, and races of Phytophthora infestans on tomato in southern California. Plant Dis. $69: 516-519$. 